\title{
KINERJA KEUANGAN PERBANKAN SYARIAH PADA MASA COVID-19 DAN STRATEGI PENINGKATANNYA
}

\author{
Ridwan Hidayat \\ Manajemen Keuangan Syariah, UIN Sunan Gunung Djati Bandung \\ Ridwanh007@gmail.com \\ Ripqi Umam \\ Manajemen Keuangan Syariah, UIN Sunan Gunung Djati Bandung \\ Umamrfq8@gmail.com \\ Ramadhani Irma Tripalupi \\ Akuntansi Syariah, UIN Sunan Gunung Djati Bandung \\ ramadhanïrmatripalupi@uinsgd.ac.id
}

\begin{abstract}
Abstrak
Tulisan ini bertujuan untuk memaparkan kinerja keuangan perbankan syariah di Indonesia pada masa pandemi Covid-19 dan strategi peningkatanya, dimana pandemi tersebut sangat berdampak buruk terhadap perekonomian. Penelitian ini merupakan penelitian kualitatif, metode yang digunakan adalah deksriptif analisis. Data dalam penelitian ini merupakan data sekunder yang teknik pengumpulan datanya menggunakan dokumentasi. Analisis data menggunakan triangulasi data yaitu, reduksi data, penyajian data, dan penarikan kesimpulan. Hasil penelitian yang diperoleh adalah; (1) kinerja keuangan perbankan syariah pada masa pandemi Covid-19 masih baik dan positif, hanya perlu ditingkatkan jika dibandingkan dengan bank konvensional; (2) strategi peningkatan kinerja keuangan bank syariah adalah restrukturisasi pembiayaan, penambahan jangka waktu pembiayaan, penyempurnaan regulasi, dan digitalisasi layanan bank; dan (3) dalam konteks ekonomi, lembaga keuangan berperan dalam memulihkan ekonomi nasional dengan memobilisasi simpanan, menyumbangkan modal risiko dalam krisis, dan mengembangkan Fintech Syariah.
\end{abstract}

Kata Kunci : Kinerja Keuangan, Perbankan Syariah, Covid-19, Strategi Peningkatan

\begin{abstract}
This paper aims to describe the financial performance of Islamic banking in Indonesia during the Covid19 pandemic and its improvement strategy, where the pandemic had a very bad impact on the economy. This research is a qualitative research, where the method used is descriptive analysis. The data in this study are secondary data whose data collection techniques use documentation. Data analysis uses data triangulation, namely, data reduction, data presentation, and drawing conclusions. The research results obtained are; (1) Islamic banking financial performance during the Covid-19 pandemic is still good and positive, only needs to be improved when compared to conventional banks; (2) strategies for improving the financial performance of Islamic banks are financing restructuring, increasing the financing period, improving regulations, and digitizing bank services; and (3) in the economic context, financial institutions play a role in restoring the national economy by mobilizing savings, contributing risk capital in a crisis, and developing Sharia Fintech.
\end{abstract}

Keywords : Perception, Preference and Musyarakah Financing Customer Attitude 


\section{Pendahuluan}

Memasuki tahun 2020 hingga triwulan IV tahun 2021, adalah masa sulit karena masih merebaknya pandemi Corona Virus Disease 2019 (Covid-19). Pandemi ini, merupakan masalah kesehatan, yang kemudian berdampak hampir di semua lini kehidupan di berbagai sektor, termasuk pelaku usaha dan sektor keuangan. Sehingga pemerintah Indonesia memutuskan untuk memperhatikan tiga sektor tersebut, yakni kesehatan, sektor riil dan perbankan (The Conversation, 2020)

Pandemi Covid-19 memberikan dampak yang signifikan pada perbankan Syariah, salah satunya menurunnya penyaluran dan pengembalian pembiayaan. Para nasabah pembiayaan kesulitan melakukan pembayaran karena menurunnya pendapatan. (Hadiwardoyo, 2020). Ini berdampak pada menurunnya kinerja perbankan Syariah dan mengganggu stabilitas perbankan Syariah. (Disemadi \& Shaleh, 2020)

"Dampak dari lemahnya sektor UMKM dan industri lainnya juga berpengaruh pada perolehan dari simpanan dana pihak ketiga dan pembiayaan pada bank syariah pada awal penyebaran Covid-19" (Ningsih \& Mahfudz, 2020) "Pandemi ini membawa risiko operasional bank syariah menjadi dua bagian yaitu risiko ke nasabah dan risiko ke bank, seperti penutupan, dan juga penurunan laba". Kemudian, menyebabkan bank sebagai lembaga intermediasi tidak berfungsi, yakni sebagai perantara yang mendukung kebutuhan dana investasi bagi sektor riil (Ilhami \& Thamrin, 2021).

Rilis media daring Bareksa menyebutkan per Juni 2020 perkembangan masih menunjukkan tren yang positif. Hal ini dilihat dari penyaluran pembiayaan, pertumbuhan asset, penghimpunan dana pihak ketiga terus meningkat. Asset mencapai Rp545,39 triliun atau bertumbuh sebesar 9,22 persen. Kemudian pembiayaan yang disalurkan mencapai Rp377,525 triliun dan dan Dana Pihak Ketiga (DPK) mencapai Rp430,209 triliun. (Malik, 2020)

Menurut data OJK, bank umum syariah menjadi kontributor terbesar dalam mendukung keuangan syariah dengan total aset Rp356,33 triliun, PYD Rp232,86 triliun dan DPK Rp293,37 triliun. Unit usaha syariah membantu kenaikan kontribusi yakni total aset senilai Rp175,45 triliun, PYD Rp134,16 triliun dan DPK Rp127,95 triliun. (Malik, 2020)

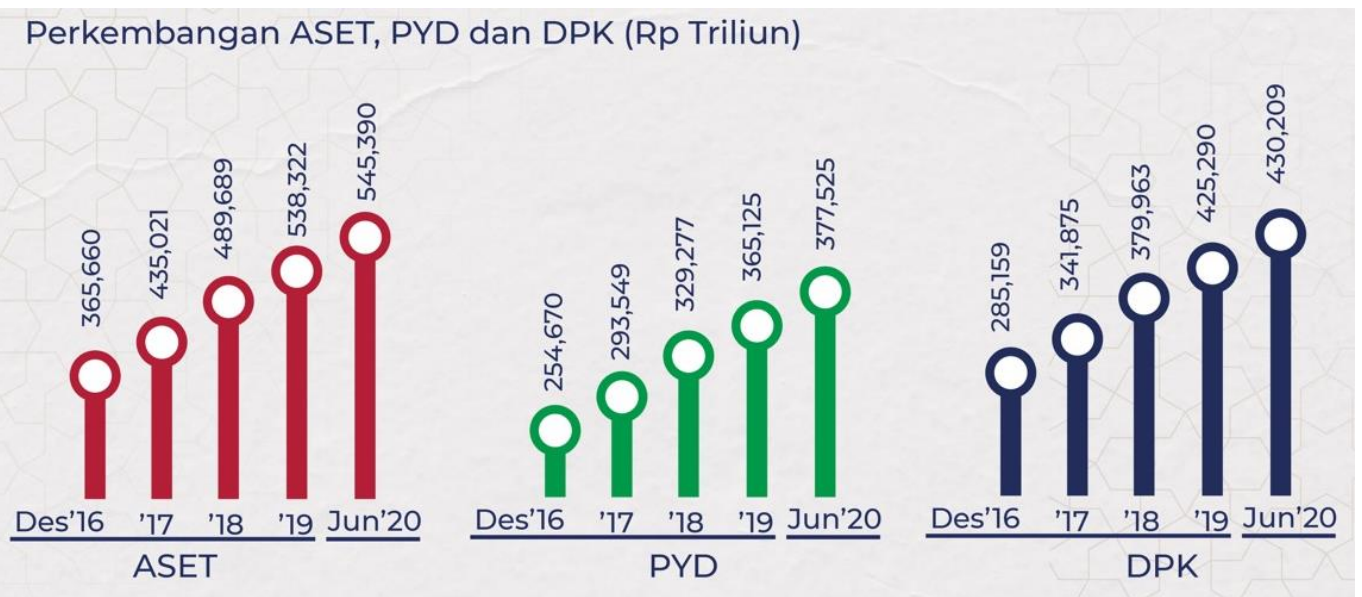

Sumber : OJK

OJK mencatat per Juni 2020, rasio kecukupan modal (CAR) perbankan syariah 21,2 persen, rasio efisensi bank (BOPO) 83,47 persen, return on asset (ROA) 1,58 persen, non 
performing financing (NPF) net 2.05 persen, NPF gross 3,37 persen, serta finance to deposit ratio (FDR) 87,11 persen. Market share perbankan syariah juga meningkat jadi 6,18 persen. Porsi market share perbankan syariah tersebut terdiri dari bank umum syariah menyumbang 65,33 persen, unit usaha syariah 32,17 persen, dan bank pembiayaan rakyat syariah 2,5 persen. (Malik, 2020)

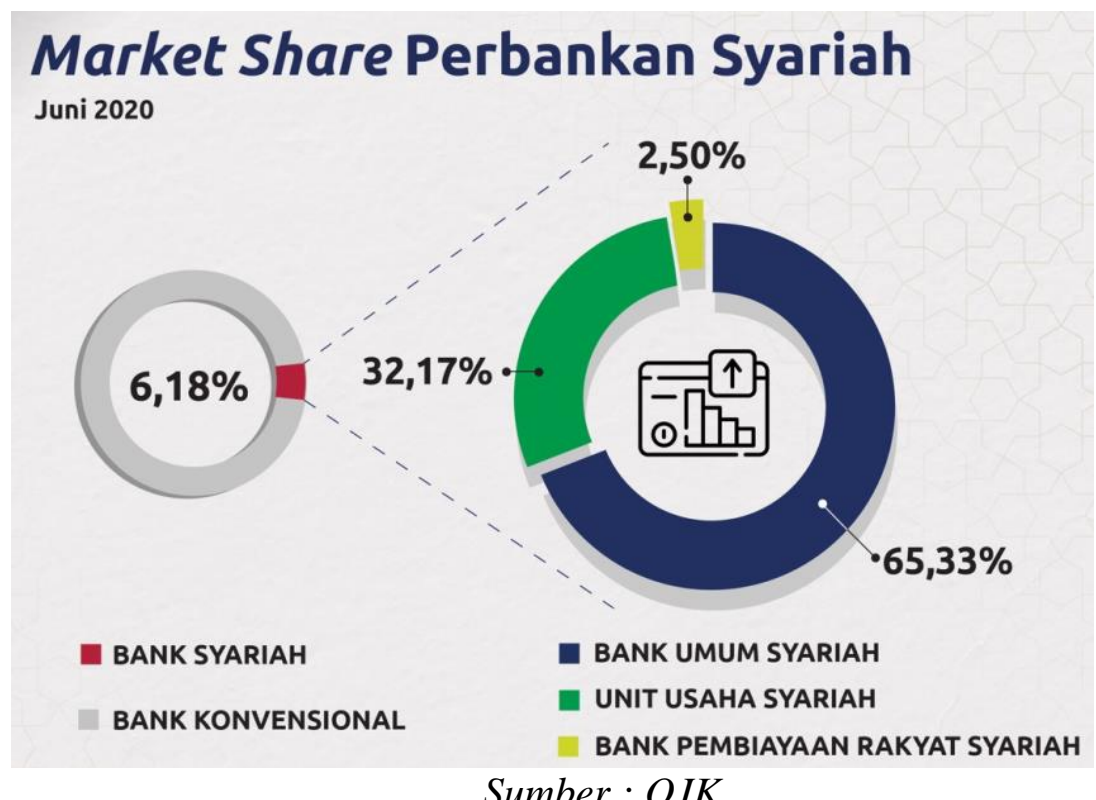

Kondisi perbankan selama pandemi Covid-19 cukup baik, termasuk perbankan syariah. Ini bisa dilihat data dari Otoritas Jasa Keuangan antara lain melalui indikator penyaluran dana, total asset, Capital Adequacy Ratio (CAR) dan Loans to Deposits Ratio (LDR) tahun 2019 dan 2020. Aset tahun 2020 mengalami kenaikan 13,14 persen dari tahun 2019. Penyaluran dana pada akhir tahun 2020 naik 8,12 persen dari tahun 2019. Dari sisi CAR mengalami kenaikan 5,01 persen. Sedangkan LDR mengalami penurunan 1,99 persen. (Otoritas Jasa Keuangan, 2021)

Kinerja perbankan syariah yang disebutkan di atas memang terlihat cukup baik selama pandemi Covid-19. Namun pada kenyataannya Covid-19 menimbulkan berbagai macam tantangan pada hampir di semua sektor. Banyak aktivitas ekonomi yang mengalami dampak termasuk sektor bank Syariah. Agar bank Syariah dapat bertahan maka bank Syariah perlu melakukan mitigasi risiko dan membuat strategi yang inovatif.

Metode lama dalam pemasaran, dan product service akan menghambat bank Syariah untuk terus bertahan. Perlu cara baru yang menjadi alternatif bagi bank sayriah agar keluar dari kondisi yang tidak tahu kapan berakhirnya. Layanan perbankan digital dapat menjadi opsi utama agar memudahkan calon nasabah, sudah banyak bank-bank konvensional menerapkan ini. Terlebih lagi, penggunaan smartphone meningkat di era pandemic ini. Menurut Global Web Index (GWI), di masa ini lebih dari 76\% pengguna internet berusia 16-64 tahun menggunakan ponsel pintar. (Hasiholan, Pratami, \& Wahid, 2020).

Salah satu kebijakan dalam pemulihan ekonomi pada masa pandemi Covid-19 adalah kebijakan makroprudensial karena mengingat peran pentingnya dalam menjaga stabilitas keuangan dan mendorong pemulihan ekonomi, di samping kebijakan fiskal dan moneter (Elena, 2020). Terkait hal ini, melihat kinerja keuangan perbankan di atas maka penting bagi perbankan syariah, turut berperan dalam pemulihan perekonomian di Indonesia 


\section{Metode}

Penelitian ini merupakan penelitian kualitatif, di mana menggunakan metode deskriptif-analisis. Sumber data pada penelitian ini adalah data sekunder, di mana peneliti mendapatkan data kinerja dari laporan $\mathrm{OJK}$, kemudian berselancar di internet untuk menambah literatur pembahasan. Teknik analisis data yang digunakan mempunyai tiga tahapan yaitu mereduksi data, melakukan penyajian data dan pengambilan kesimpulan/verifikasi. (Huberman \& Miles, 2000)

\section{Hasil dan Pembahasan}

Pada bagian ini akan dibahas mengenai kinerja keuangan perbankan syariah pada masa pandemi Covid-19, peran dan strategi perbankan syariah pada masa pandemi Covid-19, dan industri keuangan syariah dalam mendukung pemulihan ekonomi nasional.

\subsection{Kinerja Keuangan Perbankan Syariah Selama Pandemi Covid-19}

Pandemi Covid - 19 pertama kali mewabah di Wuhan Cina pada November 2019, setelah itu menyebar masuk ke Indonesia pada awal Maret 2020. Covid - 19 menimbulkan dampak pada hampir semua lini kehidupan di Indonesia sampai sekarang (triwulan III tahun 2021). Imbasnya juga sangat terasa pada perekonomian di Indonesia, termasuk perbankan syariah (Muhyiddin, 2020). Perusahaan - perusahaan baik skala besar, UMKM maupun sektor informal juga sangat terdampak. Banyak pelaku sektor riil tersebut yang mengurangi karyawan bahkan menutup usaha mereka karena operasional dan omset usaha yang terus menurun (Pakpahan, 2020).

Industri jasa keuangan syariah, khususnya perbankan syariah merupakan salah satu lini yang berperan dalam kemajuan perekonomian Indonesia beriringan dengan sektor rill karena perbankan sebagai lembaga intermediasi. Namun akibat pandemi ini, bank syariah merasakan tantangan untuk bertahan yang sangat signifikan dikarenakan pergeseran pola konsumsi, pola hidup, dan kebijakan.

Kebijakan pemerintah dalam Pembatasan Sosial Berskala Besar (PSBB) yang diberlakukan per wilayah, baik provinsi atau kabupaten/kota berdasarkan tingkat keparahan wabah yang penilaiannya ditentukan oleh pemerintah pusat melalui Kementerian Kesehatan. (Albanjari, Prihatin, \& Suprianto, 2021). Hingga kini kebijakan baru membagi zona kerawanan Covid-19 dengan zona merah dan zona hijau, dan PPKM dengan pembagian Level 1 sampai dengan Level 4 membuat Sektor perbankan kewalahan untuk bertahan, karena adanya pembatasan jam operasional dan belum lagi permasalahan pembiayaan yang macet. PSBB dan PPKM membuat beberapa kantor bank Syariah terdampak karena jumlah yang kantor terbanyak terkonsentrasi di Pulau Jawa. Sedangkan, Pulau Jawa didominasi oleh PPKM level 3 dan 4 sehingga mempenagruhi operasional mereka. (Ningsih \& Mahfudz, 2021)

Permasalahan operasional dan macetnya pembiayaan yang dialami oleh bank syariah saat ini berdampak pada kinerja keuangan syariah. Penelitian yang dilakukan oleh (Azhari \& Wahyudi, 2020), Pandemi Covid-19 mempengaruhi kinerja perbankan syariah yang ditunjukkan dengan gejolak fluktuasi terutama diawal masa pandemi Covid-19. Kinerja pada bank syariah mengalami fluktuasi pada sisi DPK dan pembiayaan. Pada sisi pembiayaan sewa mengalami penurunan yang cukup konstan pada masa pandemi. Sedangkan pada sisi equity financing mengalami pertumbuhan yang cukup signifikan dan stabil. Hal ini semakin memperkuat teori bahwa sistem bagi hasil yang digunakan pada 
produk bank syariah; equity financing mampu bertahan terhadap kondisi gejolak ekonomi domestik dan internasional.

Kinerja keuangan dikemukakan oleh (Sundjaja \& Barlian, 2003) adalah kemampuan perusahaan dalam mengelola dan mengendalikan sumber daya yang dimilikinya. Tujuannya adalah untuk mengetahui tingkat likuiditas, tingkat solvabilitas, tingkat rentablitas dan tingkat stabilitas. Menurut Ilhami, kinerja keuangan bank adalah gambaran kondisi keuangan bank suatu, dilihat dari aspek penghimpunan (funding) maupun penyaluran dana (lending) pada periode tertentu (Ilhami \& Thamrin, 2021)

Menurut salah satu lembaga yang mengatur keuangan menjelaskan bahwa kinerja keuangan perbankan syariah di masa pandemi Covid - 19 lebih baik jika dibandingkan dengan perbankan konvensional. Penyaluran pembiayaan perbankan syariah Mencapai Rp 394,6 triliun atau naik 8,08\% sepanjang tahun 2020. Sementara pembiayaan yang disalurkan industri perbankan pada periode yang sama sebanyak Rp5.482,5 triliun atau terkontraksi sebesar minus $2,7 \%$. Pembiayaan perbankan syariah tumbuh lebih pesat dibanding pertumbuhan kredit perbankan umum, ini didukung pertumbuhan DPK yang tinggi. Walaupun tidak semua indikator kinerja keuangan bank syariah baik, namun kinerja dan performanya di Indonesia menunjukan sentimen positif dan optimistis (Puspaningtyas, 2020).

OJK meyakini bahwa industri perbankan syariah akan terus tumbuh untuk beberapa tahun kedepan, selama masa pandemi Covid - 19 pun perbankan syariah bisa dikatakan sangat stabil, antara lain dengan ditinjau dari aset, pembiayaan yang diberikan dan DPK. Berikut datanya dari OJK aset di perbankan syariah pada tahun 2020 mencapai Rp 594,$\mathrm{T}$ naik dibanding tahun 2019 mencapai Rp 525,- T, sedangkan perbankan konvensional pada tahun 2020 mencapai Rp 9.178,- T pada tahun 2019 sebesar Rp 8.563,- T. Kemudian dari segi pembiayaan pada akhir tahun 2020 perbankan syariah mencapai Rp 386,- $\mathrm{T}$ sedangkan tahun 2019 mencapai Rp 357,- T, pada perbankan konvensional masing-masing sebesar Rp 5.548,- $\mathrm{T}$ dan sebesar Rp 5.684,- T. Pada perbankan konvensional pertumbuhan pembiayaannya menurun. Dilihat dari DPK, pada perbankan syariah masing-masing mencapai Rp 466 T,- naik dari tahun sebelumnya sebesar Rp 417 T,-. Di satu sisi pada perbankan konvensional sebesar Rp 5.999 T,- dan Rp 6.665 T,- , masih dibawah pertumbuhan DPK dibanding perbankan syariah. (Otoritas Jasa Keuangan, 2021)

Dilihat dari besar nominal, aset dan DPK pada perbankan syariah masih kecil, namun pertumbuhan keduanya lebih besar daripada perbankan konvensional. Pada perbankan konvensional rasio intermediasi mengalami penurunan karena Covid-19, ini bisa dilihat pertumbuhan pembiayaan (kredit) menurun. Namun secara umum resiko kredit masih dapat terkendali dengan baik dibanding pada tahun 2019. Perbankan syariah pun dapat mencapai hasil yang positif dan pembiayaannya masih tumbuh sekira 8,8 persen (Santia, 2021)

Kinerja keuangan perbankan syariah dapat dilihat melalui tingkat rasio yang dimiliki bank. Kinerja keuangan yang berupa rasio keuangan bank terutama bank syariah akan memberikan informasi kepada pemerintah, investor dan nasabah bank syariah tentang kondisi keuangan yang terjadi selama satu periode tertentu. Rasio-rasio keuangan yang dapat mencerminkan kinerja bank meliputi rasio likuiditas, rasio asset management, rasio solvabilitas dan rasio profitabilitas. (Permatasari \& Yulianto, 2018)

Dari indikator tersebut, kinerja keuangan pada perbankan syariah dapat dilihat pada tabel berikut ini: 
Tabel 1. Data Kinerja Keuangan Perbankan Syariah 2019-2020

\begin{tabular}{|c|c|c|c|}
\hline \multirow{2}{*}{$\begin{array}{c}\text { Jenis Perbankan } \\
\text { Syariah }\end{array}$} & Rasio & $\begin{array}{c}\text { 2019 } \\
\text { (dalam \%) }\end{array}$ & $\begin{array}{c}\text { Tahun } \\
\text { (dalam \%) }\end{array}$ \\
\cline { 2 - 4 } & CAR & 20,59 & 21,64 \\
\hline \multirow{4}{*}{ BUS } & ROA & 1,73 & 1,40 \\
\cline { 2 - 4 } & NPF & 1,88 & 1,57 \\
\cline { 2 - 4 } & FDR & 77,91 & 76,36 \\
\cline { 2 - 4 } & BOPO & 84,45 & 85,55 \\
\cline { 2 - 4 } & NOM & 1,92 & 1,46 \\
\hline \multirow{5}{*}{ UUS } & CAR & - & 1,81 \\
\cline { 2 - 4 } & ROA & 2,04 & 1,93 \\
\cline { 2 - 4 } & NPF & 1,89 & 96,01 \\
\cline { 2 - 4 } & FDR & 101,93 & 78,96 \\
\cline { 2 - 4 } & BOPO & 78,01 & 1,73 \\
\cline { 2 - 4 } & NOM & 2,18 & \\
\hline
\end{tabular}

Berdasarkan pada data statistik perbankan syariah yang dirilis pada website Otoritas Jasa Keuangan (OJK) dapat dilihat kinerja keuangan selama masa pandemi setahun terakhir. Peneliti mencoba menganalisisnya beberapa indikator kinerja keuangan tersebut dengan metode RGEC. Pada data CAR, yang mengukur rasio kecukupan modal yang dimiliki dapat dilihat bahwa CAR pada BUS dan UUS pada tahun 2020 adalah 21,64\% dan 1,81\%. Ini masuk pada kategori sangat sehat karena berada pada kriteria $<94 \%$.

Kemudian, kesehatan ROA pada BUS dan UUS berada pada kriteria sehat dan sangat sehat, karena pada BUS diperoleh 1,25\%<1,40\%<1,50\%, sedangkan ROA pada UUS diperoleh 1,81 > 1,50\%. Hasil ini didukung oleh penelitian (Effendi \& Hariani RS, 2020), bahwa ROA dalam kondisi krisis yang diakibatkan pandemic Covid-19 ROA bank umum syariah dan unit usaha syariah mengalami penurunan secara signifikan. Namun posisi bank syariah ROA masih positif dan masih jauh dari masalah yang mengkhawatirkan.

Selanjutnya, kriteria NPF pada bank syariah ini adalah sangat sehat karena baik BUS maupun UUS, NPF yang diperoleh adalah $<2 \%$. Hasil ini didukung oleh penelitian (Effendi \& Hariani RS, 2020) NPF bank umum syariah sama sekali tidak terganggu sedangkan NPF unit usaha syariah mengalami kenaikan yang cukup signifikan namun kedua-dua masih dalam batas aman diaman NPF-nya masih dibawah 5\%. Dengan demikian dari sisi NPF menunjukkan bank syariah masih tahan terhadap gelombang covid-19.

Pada rasio FDR, di mana Likuiditas yang tersedia pada bank syariah harus berada pada kecukupan yang stabil, tidak boleh berada terlalu tinggi atau terlalu rendah, karena ketidakstabilan tersebut akan mengganggu pada pemenuhan kebutuhan operasional dan menurunkan efisiensi sehingga berdampak pada profitabilitas (Effendi \& Hariani RS, 2020). FDR pada BUS adalah 75\% $576,36 \%<85 \%$ yaitu pada kategori sehat, dan FDR pada UUS adalah $85 \% \leq 96,01<100 \%$ berada pada kategori cukup sehat.

Lalu BOPO, pada BOPO yang rendah mengindikasikan bahwa bank semakin efisien dalam menekan beban operasionalnya (Rivai \& Ismail, 2013). BOPO yang diperoleh 
BUS adalah $85,55 \%$ dimana $<94 \%$ dan berada pada kategori sangat sehat, begitupula pada UUS diperoleh BOPO 78,96 < 94\% sehingga berada pada kategori sangat sehat.

Dengan demikian, sampai pada temuan akhir bahwa pada dasarnya selama Covid19 tahun 2019 dan 2020 bank syariah khususnya BUS dan UUS mendapatkan kinerja keuangan yang baik. Namun jika dibandingkan dengan kinerja perbankan konvensional, bank syariah masih perlu melakukan peningkatan kinerja, karena dari sisi total aset, market share, DPK, dan rasio keuangan lainnya masih jauh di bawah bank konvensional.

\subsection{Peran, Tantangan dan Strategi Perbankan Syariah pada Masa Pandemi Covid-19}

Sektor perbakan memiliki peran yang strategi untuk memajukan perekonomian masyarakat. Melalui pembiayaan dari perbankan Syariah maka akan membantu masyraat untuk lebih produktif karena mendapat bantuan modal dari perbankan. Sayangnya, diera pandemi ini semua hal harus diadaptasi dengan cara baru termasuk operasional perbankan Syariah. Bank Syariah harus menciptakan strategi baru yang lebih inovatif dan dapat memitigasi risiko yang sudah dihadapi oleh bank Syariah sekarang ini dan kondisi ekonomi dan lingkungan yang tidak menentu saat ini. Hal ini menunjukkan perbankan syarih menghadapi tantangan yang lebih besar untuk dapat memajukan perbankan Syariah. Maka dari itu, sudah saatnya Perbankan Syariah mulai merevisi kembali strategi, mengingat tidak ada yang mengetahui kapan Covid-19 akan berakhir. (Tahliani, 2020)

\section{Tantangan Peningkatan Kinerja Keuangan Perbankan Syariah}

Kondisi pandemi saat ini memberikan tantangan terhadap perbankan syariah seperti pada pola transaksi fisik menjadi virtual. Alhasil, bank syariah harus segera beradaptasi dengan kondisi pandemi virus Korona dengan menerapkan strategi baru, dan kembali pada jalur kinerja yang good performance. Harapannya, fungsi intermediary bank berjalan smooth dan mampu menjadi pengungkit pertumbuhan ekonomi nasional Indonesia di era new normal. (Habibah, 2020).

Tantangan perbankan syariah bukan hanya berubahnya transaksi fisik menjadi nonfisik tetapi ada juga tantangan lainya seperti masalah permodalan, daya saing layanan dan produk perbankan syariah, minimnya SDM perbankan syariah (Bank Indonesia, 2021). Kemudian, ada beberapa kendala yang harus diselesaikan diantaranya market share keuagan syariah yang masih rendah dari total aset nasional, juga dalam hal indeks inklusi, keuangan syariah masih jauh tertinggal dari indeks nasional. Hal lainnya adalah model bisnis syariah yang masih minim, maka diperlukan inovasi-inovasi dari para pelaku di industri keuangan syariah (perbankan syariah), juga dibutuhkan teknologi yang mumpuni mengingat jaman sekarang teknologi semakin canggih, juga hal penting lainnya sumber daya insani atau manusia (SDM) yang mempunyai keahlian dibidang keuangan syariah baik secara kuantitas maupun kualitas (Bank Indonesia, 2021)

Salah satu kelebihan industri perbankan syariah terletak pada basis pembiayaan yang dilakukan. Salah satunya adalah underlying asset, atau model kontrak dengan real economy seperti yang dilakukan oleh perbankan syariah pemerintah yang melakukan merger bulan-bulan yang lalu (menjadi Bank Syariah Indonesia). Hal ini bisa menjadi pilihan bagi masyarakat untuk menyimpan dana, juga dari sisi fee based income, perbankan syariah terutama BSI (Bank Syariah Indonesia) mengalami peningkatan selama 
masa pandemi Covid-19. Peningkatan ini bersumber dari biaya transaksi digital dan bisnis emas baik tabungan maupun gadai (Wulandhari, 2021)

Pada Juni 2020, total aset perbankan syariah tumbuh 9,22 persen secara tahunan menjadi Rp 545,4 triliun. Realisasi itu lebih tinggi dibandingkan perbankan konvensional yang hanya tumbuh 4,89 persen. Menurutnya, pertumbuhan kinerja perbankan syariah di tengah pandemi Covid - 19 utamanya didorong oleh 3 hal. Pertama, meningkatnya kesadaran gaya hidup halal. Ini ditunjukan oleh munculnya beberapa komunitas. Kemudian, adanya dukungan dari pemerintah terhadap keuangan syariah, yang terefleksikan dengan pembentukan Komite Nasional Ekonomi dan Keuangan Syariah (KNEKS) hingga pembangunan infrastruktur penunjang industri halal (Ramli, 2020).

Sektor perbankan syariah yang menguasai porsi terbesar keuangan syariah, mengalami dampak dari pandemi Covid - 19. Sebagai lembaga perantara keuangan, ditinjau dari NPF (Non Performing Finance) atau pembiayaan bermasalah, bank mengalami peningkatan. Lembaga Keuangan Syariah mengalami peningkatan resiko baik resiko operasional, resiko pembiayaan, resiko pasar, dan seterusnya. Demikian pula di pasar modal, saham di pasar bursa, termasuk saham syariah mengalami koreksi sebesar 20-30 persen. Sebagai akibatnya, banyak investor yang melepas sahamnya dan terjadi capital outflow besar-besaran karena meningkatkan resiko investasi Indonesia.

Bank Indonesia (BI) menilai kinerja perbankan syariah melemah dalam beberapa waktu terakhir. Hal ini sebagaimana disampaikan oleh Yuda Agung Asisten Gubernur Bank Indonesia - Bidang Stabilitas sistem keuangan dan kebijakan Makroprudensial- , bahwa perbankan syariah perlu mewaspadai beberapa hal di tengah pandemi Covid-19. (Bank Indonesia, 2021). Likuiditas juga menurun dari sebelumnya posisi alat likuid per dana DPK sebesar 26 persen menjadi 20 persen. Namun demikian, sistem keuangan secara makro agregat tidak ada masalah, dan secara umum keuangan syariah tumbuh relatif baik (Azizah, 2020)

\section{Strategi Perbankan Syariah pada Masa Covid-19}

Menurut Heru, untuk menyelesaikan tantangan yang dialami perbankan syariah pada masa pandemi ini yaitu dengan cara berkolaborasi dengan berbagai pihak. Sementara itu ada tiga pilar agar market share bank syariah bisa mendominasi. Pertama, penguatan identitas perbankan syariah, sinergi ekosistem ekonomi syariah, dan penguatan proses, pengaturan dan pengawasan. (Hasibuan, 2021)

Dalam rangka meminimalisir dampak Covid-19, termasuk di sektor industri perbankan, pemerintah, melalui Otoritas Jasa Perbankan (OJK) mengeluarkan kebijakan stimulus perekonomian Nasional sebagai kebijakan countercyclical dampak penyebaran corona virus disease 2019 penerbitan POJK No. 11/POJK.03/2020. Kebijakan ini mengatur bank untuk mendukung stimulus pertumbuhan ekonomi, khususnya bagi debitur yang terkena dampak pandemi Covid-19 termasuk debitur UMKM, namun tetap memperhatikan prudential banking principle. Salah salah satunya memuat tentang restrukturisasi pembiayaan atau kredit.

Restrukturisasi menjadi salah satu strategi bank syariah untuk dapat memberikan sedikit kemudahan bagi masyarakat, juga tetap menjaga income bagi bank syariah dari segi pembiayaan. Selain itu strategi lain ialah meninjau kembali jangka waktu pelunasan atau pembayaran angsuran dari pembiayaan menjadi tiga sampai dengan enam bulan ke depan. 
Kebijakan restrukturisasi merupakan bagian dari kebijakan makroprudensial. (BI, 2020) Maka dari itu, bank syariah ini dapat menjadi solusi untuk mengatasi permasalahan perekonomian yang dialami oleh nasabah.

Restrukturisasi pembiayaan merupakan kemudahan yang diberikan oleh bank syariah untuk melakukan pembayaran angsuran dengan meninjau kembali seperti memperpanjang jangka waktu pembiayaan, memperkecil nominal angsuran, intinya bukan berarti menghapus kewajiban angsuran. Kebijakan ini sudah berlaku sejak awal pandemi, yang mana kebijakannya diberikan kepada bank syariah. Dengan begitu diharapkan bank syariah dapat memperbaiki kinerjanya.

Kemudian karena pandemi masih berlangsung, POJK tersebut diperpanjang melalui POJK Nomor 48/POJK.03/2020 tentang Perubahan Atas Peraturan Otoritas Jasa Keuangan Nomor 11/POJK.03/2020 tentang Stimulus Perekonomian Nasional sebagai Kebijakan Countercyclical Dampak Penyebaran Coronavirus Disease 2019 (POJK Perubahan atas POJK Stimulus Covid-19) yang berlaku 31 Maret 2022.

Untuk mengantisipasi potensi masalah di sisi mikro ini, BI berupaya melalui penyempurnaan regulasi. Seperti kebijakan untuk pinjaman likuiditas jangka pendek (PJLP) dan pinjaman likuiditas khusus (PLK) terbaru. Mempertimbangkan bahwa tidak semua indikator kinerja keuangan sehat, dan begitu dahsyatnya dampak pandemi ini. Maka pada masa pandemi Covid-19 ini, perlu adanya strategi untuk menjaga pertumbuhan perbankan syariah. Strategi ini adalah rencana aksi organisasi (perbankan syariah) untuk mencapai misi. Setiap bidang fungsional sebaiknya memiliki strategi untuk mencapai misi bank untuk membantu organisasi untuk mencapai seluruh misinya (Ningsih \& Mahfudz, 2021)

Strategi yang diterapkan terkait kebijakan pemerintah di atas, pihak bank tinggal menindaklanjuti. Kemudian, Michael Porter dalam (Ronde \& Heizen, 2001) menegaskan, bahwa perusahaan mencapai misi melalui tiga cara konsep: (1) Diferensiasi, (2) Kepeloporan biaya, (3) Respon yang cepat. Penerapan pada bank syariah yaitu diferensiasi, yakni bank membuat diferiansi produk atau layanan terutama berbasis digital (Mawarni, Fasa', \& Suharto, 2021) yang masa ini sedang sangat dibutuhkan masyarakat. Kepeloporan biaya, bagaimana biaya bersaing dengan bank konvensional, dan respon yang cepat baik dalam pelayanan mesin (digital) maupun pelayanan non mesin (on the counter).

Sebagai entitas bisnis tentunya tidak bisa hanya memandang Covid-19 sebagai sebuah bencana, namun juga harus bisa menangkap ini sebagai tantangan yang mana mendorong bank syariah keluar dari zona nyamannya dan menjadikannya peluang. Peluang tersebut dapat dioptimalkan dengan ekspansi bisnis, peningkatan layanan digital, dan lain sebagainya. Dengan layanan digital akan memperluas jangkauan bisnis dari bank syariah. Maka sudah seharusnya bagi bank syariah mengimplementasikan lebih masif layanan digital yang terdapat dalam satu aplikasi canggih. (Habibah, 2020).

OJK menyebutkan bahwa layanan perbankan digital adalah aktivitas dan transaksi pada perbankan dengan menggunakan sarana electronik atau digital milik bank, dan/atau melalui media digital milik calon nasabah dan/atau nasabah bank, yang dilakukan secara mandiri. Digitalisasi layanan bank memungkinkan bagi nasabah dan calon nasabah untuk memperoleh layanan perbankan secara mandiri(self service) tanpa harus datang langsung ke bank (Puspaningtyas, 2020). 
Tantangan transformasi pemanfaatan teknologi digital lebih dari sekedar menyediakan layanan online dan mobile banking, perlu berinovasi dalam menggabungkan teknologi digital dengan interaksi nasabah, dalam hal ini temuan-temuan teknologi baru tersebut haruslah mempermudah dan memberikan kenyamanan bagi pengguna dalam mengakses layanan perbankan syariah. ini juga berdampak bagi citra perusahaan. Apabila layanan digital tidak mampu memberikan kemudahan dan kenyamanan penggunanya maka bank syariah gagal dalam menciptakan inovasi teknologi. Maka dari itu peralihan dari tradisional ke transaksi yang serba digital harus mempertimbangkan banyak hal.

Digitalisasi akan berdampak positif pada pertumbuhan bisnis secara umum. Maka di era technology disruption saat ini, setiap industri harus siap bergerak menghadapi perubahanperubahan dinamis. Industri perbankan syariah pun mau tidak mau harus menyesuaikan diri dengan perkembangan teknologi yang ada, digitaliasi mengharuskan bank syariah melakukan pembaharuan layanan, mengingat peralihan dunia perbankan konvensional menjadi digital dapat meningkatkan efesiensi proses kerja dan meningkatkan kualitas layanan nasabah, dengan melakukan digitalisasi, bank sudah melakukan investasi jangka panjang untuk masa depan, dan diproyeksikan layanan digital menjadi salah satu pendorong utama pertumbuhan industri perbankan secara berkelanjutan. (Sumadi, 2020).

\subsection{Industri Keuangan Syariah dalam mendukung Pemulihan Ekonomi Nasional}

Meskipun ditengah tingginya ketidakpastian dalam sektor ekonomi akibat pandemi Covid-19 tapi keuangan syariah dapat tumbuh baik. Indonesia merupakan negara yang mayoritas penduduknya muslim, sehingga berpotensi besar bagi industri keuangan syariah dalam mendukung pemulihan ekonomi di Indonesia. Apalagi terkini sedang marak dengan adanya halal style. Hal ini menyebabkan keuangan syariah dapat berperan penting dalam pemulihan ekonomi nasional. Selain itu, pertumbuhan juga didukung oleh perkembangan aset keuangan syariah dimana semakin banyaknya lembaga jasa keuangan syariah di Indonesia. Saat ini terdapat 14 bank umum syariah, 20 unit usaha syariah, dan 162 BPR syariah. Di sektor pasar modal memiliki 464 saham syariah, 145 sukuk korporasi, dan 282 reksadana syariah, dan 66 sukuk negara, dan 215 lembaga jasa keuangan syariah non bank (Azizah, 2020)

Menurut ketua umum Masyarakat Ekonomi Syariah (MES) untuk memulihkan ekonomi saat ini peran semua sektor ekonomi sangat dibutuhkan termasuk keuangan syariah. Di masa pandemi ini, keuangan syariah tumbuh cukup tinggi sebesar 21,58 persen, dibanding tahun 2019 mencapai 13,84 persen. Bahkan pembiayaan bank umum syariah mencatatkan pertumbuhan 9,5 persen di tengah kontraksi kredit perbankan nasional sebesar $-2,41$ persen. Sepanjang tahun 2020, Indonesia diakui sebagai negara terbaik ke-2 dalam bidang ekonomi dan keuangan syariah yaitu dalam Refinitiv Islamic Finance Development Report 2020 dan mendapat ranking ke-4 untuk sektor ekonomi syariah, serta peringkat ke-6 untuk keuangan syariah, sehingga Indonesia diapresiasi dunia internasional.

Gerakan lain dalam rangka inovasi atau difersifikasi produk, salah satunya adalah untuk pemberdayaan ummat dalam pendirian dan pengembangan Bank Wakaf Mikro (BWM), peningkatan kapasitas lembaga keuangan syariah. Untuk itu MES harus berkontribusi langsung dan mendorong perkembangan ekonomi digital dan financial 
technology (fintech) (Rasidi, Budi, \& Hatmoko, 2021). Dengan demikian dengan program-program tersebut diharapkan dapat membantu dalam pemberdayaan ummat terutama pelaku UMKM. Dalam SDM ekonomi dan keuangan syariah antara lain melalui pelatihan dan sertifikasi profesi, E-Learning Ekonomi Syariah, serta pemberian beasiswa Ekonomi Syariah bisa dilakukan juga oleh MES (Sitanggang, 2021).

Asosiasi Bank Syariah Indonesia (Asbisindo) menyatakan, bahwa pemulihan ekonomi di Indonesia yang terdampak akibat pandemi ini, bisa diatasi dengan berkontribusinya lembaga keuangan syariah terutama perbankan syariah. (Handoyo, 2021) Industri perbankan memiliki peran sangat penting bagi perekonomian global. Dalam konteks ekonomi, lembaga keuangan berperan dalam memobilisasi simpanan untuk investasi produktif serta memfasilitasi arus modal pada berbagai sektor, sehingga dapat merangsang pertumbuhan investasi dan meningingkatkan produktivitas. Disisi lain, pertumbuhan perbankan syariah juga menunjukkan trend positif. (Diana, Sulastiningsih, Sulistya, \& Purwati, 2021).

Hal ini bisa dilihat dari kondisi keuangan syariah saat ini sangat baik seperti dalam aset, pembiayaan maupun DPKnya. Dalam sebuah riset disebutkan memang perkembangan bank syariah di Indonesia telah menjadi sorotan dunia, seperti dalam majalah Forbes ada 3 yang menjadi bank terbaik dunia tahun 2021 yaitu Bank Syariah Indonesia Tbk (BSI), BCA syariah dan Bank Muamalat Indonesia (BMI) (Handoyo, 2021). Ada 3 cara yang menjadi acuan Asbisindo pada perbankan syariah diantaranya: (a) Menghimpun semua potensi pada bank syariah di Indonesia. Sehingga siar ekonomi syariah sebagai dakwah bilhal akan meningkatkan kesejahteraan umat; (b) Membina dan mengembangkan bank syariah sehingga diharapkan menjadi bank yang sehat, berkembang dan memberikan manfaat bagi masyarakat; (c) Menjadi mitra utama bagi pemerintah dan regulator dalam mengembangkan perbankan syariah di Indonesia.

Kemudian, menyumbangkan modal risiko dalam krisis. Oleh karena itu, penyediaan modal komersial merupakan salah satu cara untuk mengurangi dampak krisis. Beberapa cara kebijakan lain yang dapat digunakan untuk penyediaan modal ini, seperti lebih mendorong relaksasi bank syariah, restrukturisasi atau menunda pemberian kredit syariah atau pembayaran keuangan dalam beberapa bulan ke depan. Agar lebih kuat, diperlukan pembinaan untuk mendukung dan memperkuat permodalan yang diberikan oleh bank syariah atau lembaga keuangan syariah agar dapat mempertanggungjawabkan mereka. Modal komersial dapat diikuti dengan pinjaman qard al-hasan. Dalam terminologi ekonomi atau keuangan hukum Islam, qard al-hasan adalah pembiayaan yang termasuk dalam akad tabarru' atau pinjaman yang tidak menerima pendapatan (keuntungan) tetapi selalu menekankan pada pengembalian. (Azhari \& Wahyudi, 2020).

Keuangan syariah saat pandemi Covid-19 ini sangat baik sehingga dapat mendukung dalam pemulihan ekonomi nasional, salah satunya melalaui pemberdayaan ummat. Memang pandemi ini sangat berdampak terhadap ekonomi namun untuk keuangan syariah ternyata tumbuh baik dibanding dengan konvensional. Untuk itu industri keuangan syariah harus menghadirkan produk syariah yang sesuai dengan keinginan ummat, sehingga pemasaran keuangan syariah akan semakin meningkat juga berdampak pada pemulihan ekonomi nasional dan pemberdayaan UMKM. Seperti dengan adanya produk murah, pelayanan bagus dan aksesnya mudah.

Untuk mendukung semua itu, OJK mengeluarkan roadmap untuk peningkatan literasi keuangan syariah berbasis digital yang sesuai pada saat pandemi ini. Dengan 
strategi yang ini, maka peran keuangan syariah dapat lebih memulihkan dan meningkatkan ekonomi nasional. Strategi ini didukung oleh BI dengan mengeluarkan stimulus kebijakan dalam hal percepatan digitalisasi pada perbankan, misalnya digitalisasi sistem pembayaran (BI: 2020). Dalam berperan program pemulihan ekonomi nasional, salah satunya BSI menyalurkan pembiayaan ke sektor UMKM atau non UMKM dengan leverage yang telah ditentukan. Dengan cara memberikan pembiayaan 2 kali pada periode 1 dan periode kedua 1,5 kali dari penempatan dana (Putri, 2021)

Finansial teknologi syariah dapat mempermudah para pelaku pasar dalam bertransaksi. Selain itu juga, kemajuan Fintek akan meningkatkan kesejahteraan umat karena dapat digunakan pula untuk kepentingan penghimpunan social finance, seperti zakat, waqaf, infaq, dan shadaqah. Bagi UMKM, kehadiran Fintek ini akan mengembang market share melalui kehadiran market place dan keikutsertaan UMKM tersebut untuk terjun ke dunia market place. Market place notabenenya menggunakan Fintek sebagai system pembayarannya, sehingga ini akan mempermudah juga bagi UMKM untuk penjualan dan pembayaran. (Hiyanti \& dkk, 2020)..

\section{Kesimpulan}

Penelitian ini menemukan kesimpulan akhir bahwa pertama, kinerja keuangan perbankan syariah di masa pandemi Covid-19 masih menunjukkan tren yang positif, hanya saja jika dibandingkan dengan perbankan konvensional, perbankan syariah masih harus meningkatkan kinerja keuangannya. Kedua, Industri Perbankan Syariah memiliki peran yang strategis dalam pembangunan ekonomi rakyat, berkontribusi dalam melakukan transformasi perekonomian pada aktivitas ekonomi produktif, bernilai tambah dan inklusif. Namun bank syariah juga memiliki tantangan yang harus dihadapi yaitu, Tantangan perbankan syariah bukan hanya berubahnya transaksi fisik menjadi nonfisik tetapi ada juga tantangan lainya seperti masalah permodalan, daya saing layanan dan produk perbankan syariah, minimnya SDM perbankan syariah. Maka dari itu, diperlukan strategi diantaranya, restrukturisasi pembiayaan, penambahan jangka waktu pembiayaan, atau dengan cara memberikan kelonggaran masa tenggang 3 - 6 bulan kedepan, penyempurnaan regulasi, dan digitalisasi layanan bank. Industri perbankan memiliki peran sangat penting bagi perekonomian global. Ketiga, dalam konteks ekonomi, lembaga keuangan berperan dalam memulihkan ekonomi nasional dengan memobilisasi simpanan untuk investasi produktif serta memfasilitasi arus modal pada berbagai sektor, menyumbangkan modal risiko dalam krisis, dan mengembangkan Fintech Syariah yang mendukung UMKM serta memberdayakan umat lainnya

\section{REFERENSI}

Santia, T. (2021, Februari 25). OJK Sebut Kinerja Kenangan Perbankan Syariah Lebih Kinclong Dibanding Konvensional. Retrieved from Merdeka: https://www.merdeka.com/uang/ojk-sebut-kinerja-keuangan-perbankan-syariahlebih-kinclong-dibanding-konvensional.html

Albanjari, F. R., Prihatin, R., \& Suprianto. (2021). Analisa Dampak Kebijakan Pemerintah Terhadap Kinerja Keuangan Bank Umum Syariah di Indonesia Pada Era Pandemi Corona Virus Disease-19. MUSYARAKAH: Journal of Sharia Economics (MJSE), Vol.1, No.1, 9-19. 
Azhari, A. R., \& Wahyudi, R. (2020). Analisis Kinerja Perbankan Syariah di Indonesia : Studi Masa Pandemi Covid-19, Jurnal Ekonomi Syariah Indonesia. Jumal Ekonomi Syariah Indonesia Vol. X No. 2.

Azizah, A. N. (2020). Bos OJK: Sektor Keuangan Syariah Siap Dukung Pemulihan Ekonomi Nasional. Retrieved Agustus 12, 2021, from Bisnis ID: https:// finansial.bisnis.com/read/20200921/231/1294349/bos-ojk-sektorkeuangan-syariah-siap-dukung-pemulihan-ekonomi-nasional

Bank Indonesia. (2021, Maret 23). Laporan Ekonomi dan Keuangan Syariah. Retrieved from Bank Indonesia: https://www.bi.go.id/id/LEKSI-2020/default.aspx

Diana, S., Sulastiningsih, Sulistya, E., \& Purwati. (2021). Analisis Kinerja Keuangan Perbankan Syariah Indonesia pada Masa Pandemi Covid-19. Jurnal Riset Akuntansi dan Bisnis Indonesia, Vol 1, No. 1.

Disemadi, H. S., \& Shaleh, A. I. (2020). Banking credit restructuring policy amid COVID-19 pandemic in Indonesia. Jurnal Inovasi Ekonomi, 5(02).

Effendi, I., \& Hariani RS, P. (2020). Dampak Covid 19 Terhadap Bank Syariah. Ekonomikawan: Jurnal Ilmu Ekonomi dan Studi Pembagunan, Vol. 20, No. 2.

Elena, M. (2020, Desember 2020). Sri Mulyani Ungkap Kinerja Bank Syariah Lebih Oke dari Bank Konvensional. Retrieved Agustus 12, 2021, from https://finansial.bisnis.com/read/20201229/231/1336389/sri-mulyani-ungkapkinerja-bank-syariah-lebih-oke-dari-bank-konvensional

Habibah, N. F. (2020). TANTANGAN DAN STRATEGI PERBANKAN SYARIAH DALAM MENGHADAPI COVID-19. I $q$ t $i$ s $h$ o d $i$ a $b \mathrm{~V}$ o $l 2 \mathrm{~N}$ o 1.

Hadiwardoyo, W. (2020). Kerugian ekonomi nasional akibat pandemi Covid-19. Baskara: Journal of Business and Entrepreneurship, 2(2), 83-92.

Handoyo. (2021, Mei 29). Asbisindo: Bank syariah harus berperan mendorong pemulihan ekonomi nasional. Retrieved Agustus 2021, 2021, from Kontan.co.id: https://keuangan.kontan.co.id/news/asbisindo-bank-syariah-harus-berperanmendorong-pemulihan-ekonomi-nasional

Hasibuan, L. (2021, Februari 25). OJK: Kinerja Perbankan Syariab Lebih Baik dari Konvensional. Retrieved from CNBC Indonesia: https://www.cnbcindonesia.com/syariah/20210225150734-29-226150/ojkkinerja-perbankan-syariah-lebih-baik-dari-konvensional

Hasiholan, T. P., Pratami, R., \& Wahid, U. (2020). Pemanfaatan Media Sosial Tik Tok sebagai Media Kampanye Gerakan Cuci Tangan di Indonesia untuk Mencegah Covid-19. Communiverse: Jurnal Ilmu Komunikasi, 5(2), 70-80.

Hiyanti, H., \& dkk. (2020). Peluang dan Tantangan Fintech (Financial Technology) Syariah di Indonesia. urnal Ilmiah Ekonomi Islam, Volume 5, Nomor 3.

Huberman, A. M., \& Miles, M. B. (2000). Métodos para el manejo y el análisis de datos. Denman CA, Haro JA (comp.). Por los rincones. Antología de métodos cualitativos en la investigación social. Hermosillo: El Colegio de Sonora, 253-300.

Ilhami, \& Thamrin, H. (2021). ANALISIS DAMPAK COVID 19 TERHADAP KINERJA KEUANGAN PERBANKAN SYARIAH DI INDONESIA. JURNAL TABARRU' : ISLAMIC BANGKING AND FINANCE, VOL. 4, NO. 1. 
Malik, A. (2020, September 23). OJK : Aset \& Market Share Perbankan Syariah Meningkat di Masa Pandemi, Ini Datanya. Retrieved from Bareksa: https://www.bareksa.com/berita/pasar-modal/2020-09-23/ojk-aset-marketshare-perbankan-syariah-meningkat-di-masa-pandemi-ini-datanya,

Mawarni, R., Fasa', M. I., \& Suharto. (2021). Penerapan Digital Banking Bank Syariah Sebagai Upaya Customer Retantion Pada Masa Covid-19 . AL-IQTISHOD: Jurnal Pemikiran dan Penelitian Ekonomi Islam, Volume 9 Issue 2.

Muhyiddin. (2020). Covid-19, New Normal dan Perencanaan Pembangunan di Indonesia. The Indonesian Journal of Development Planning, Volume IV No. 2.

Ningsih, M. R., \& Mahfudz, M. S. (2020). Dampak Pandemi Covid-19 Terhadap Manajemen Industri Perbankan Syariah: Analisis Komparatif. POINT: Jurnal Ekonomi Dan Manajemen, 2(1).

Ningsih, M. R., \& Mahfudz, M. S. (2021). DAMPAK PANDEMI COVID-19 TERHADAP MANAJEMEN INDUSTRI PERBANKAN SYARIAH: ANALISIS KOMPARATIF. POINT: Jurnal Ekonomi Dan Manajemen, 2(1).

Otoritas Jasa Keuangan. (2021, Februari 25). Roadmap Pengembangan Perbankan Indonesia 2020 - 2025. Retrieved from https://www.ojk.go.id/id/berita-dan-kegiatan/infoterkini/Pages/-Roadmap-Pengembangan-Perbankan-Indonesia-2020---2025.aspx

Pakpahan, A. K. (2020). COVID-19 dan Implikasi Bagi Usaha Mikro, Kecil, dan Menengah. Jurnal Ilmiah Hubungan Internasional: Edisi Khusus .

Permatasari, D., \& Yulianto, A. R. (2018). ANALISIS KINERJA KEUANGAN : KEMAMPUAN BANK SYARIAH DALAM PENYALURAN PEMBIAYAAN. Jurnal Akuntansi Indonesia, Vol 7, No 1.

Puspaningtyas, L. (2020, September 27). Ekonom: Kondisi Perbankan Syariah Lebih Baik Saat Pandemi. Retrieved Agustus 13, 2021, from Republika: https://www.republika.co.id/berita/qhb6pz370/ekonom-kondisi-perbankansyariah-lebih-baik-saat-pandemi

Putri, I. (2021, Mei 5). Industri Kenangan Syariah Tumbuh di Tengah Pandemi, Ini Strategi OJK. Retrieved Agustus 14, 2021, from Detikfinance: https:// finance.detik.com/beritaekonomi-bisnis/d-5559455/industri-keuangan-syariah-tumbuh-di-tengahpandemi-ini-strategi-ojk

Ramli, R. R. (2020, September 29). Kinerja Perbankan Syariah Dinilai Lebih Baik Dibandingkan Bank Konvensional. Retrieved from Kompas.com: https://money.kompas.com/read/2020/09/29/141908026/kinerja-perbankansyariah-dinilai-lebih-baik-dibandingkan-bank-konvensional

Rasidi, Y. S., Budi, C. S., \& Hatmoko, P. A. (2021). FINTECH SYARIAH ALTERNATIF PENDANAAN UMKM PADA MASA PANDEMI COVID-19 DI INDONESIA. Finansha-Journal of Sharia Financial Management, 2(1), 1-10.

Rivai, V., \& Ismail, R. (2013). Islamic Risk Management for Islamic Bank. Jakarta: Gramedia Pustaka Utama.

Ronde, B., \& Heizen, J. (2001). Competitive Strategy: Techniques for Analizing Industries \& Competitors. Jakarta: Penerbit Salemba Empat.

Sitanggang, L. (2021, Januari 24). MES tingkatkan kontribusi keuangan syariah untuk pemuliban ekonomi. Retrieved from Keuangan Kontan: https://keuangan.kontan.co.id/news/mes-tingkatkan-kontribusi-keuangansyariah-untuk-pemulihan-ekonomi 
Kinerja Keuangan Perbankan Syariah pada Masa Covid-19 dan Strategi Peningkatannya...

Sumadi. (2020). Menakar Dampak Fenomena Pandemi Covid-19 Terhadap Perbankan Syariah. Jurnal HES, Volume 3, Nomor 2, 145-162.

Sundjaja, R. S., \& Barlian, I. (2003). Manajemen Keuangan Satu. Edisi Kelima. Jakarta: Literata Lintas Media.

Tahliani, H. (2020). TANTANGAN PERBANKAN SYARIAH DALAM MENGHADAPI PANDEMI COVID-19. Madani Syariah, Vol. 3 No.2.

The Conversation. (2020). Bagaimana Pandemi COVID-19 Bisa Memicu Krisis Perbankan di Indonesia. Retrieved Agustus 12, 2021, from https://theconversation.com

Wulandhari, R. (2021, Mei 28). Kinerja Perbankan Syariab Lebib Baik Dibanding Konvensional. Retrieved from Republika: https://republika.co.id/berita/qtsm7r383/kinerjaperbankan-syariah-lebih-baik-dibanding-konvensional 